\title{
Epilogue: A Personal Perspective on Afta 26 Yia: Collaborative Research in Vanuatu since Independence ${ }^{1}$
}

\author{
Margaret Jolly
}

The Vanuatu Kaljoral Senta (VKS) was the venue this week for a unique conference. Conjointly organised by Director Ralph Regenvanu and a team of young Australian researchers, Jack Taylor, Nick Thieberger and Stephen Zagala, it was focused on the theme of collaboration in research, wok tugeta. But collaboration was not just the theme but the practice. The conference was well timed between the annual workshops of women and men fieldworkers of the VKS. Many fieldworkers and other ni-Vanuatu presented papers and participated in the conference. And although the conference was advertised to start in Bislama and then move into English and French, in the event most of the presentations and discussions were in Bislama. From the opening stirring speeches by Chief Paul Tahi, President of the Malvatumauri National Council and by Chief Murmur of Mangaliliu, reflecting on his conversion from Presbyterian elder to kastom jif, to the closing funny stories by Bob Tonkinson about his anthropological research in Mele-Maat and Ambrym during the colonial period, the three days offered a feast for all participants.

Several overseas researchers who started work before independence participated: Michael Allen (Ambae), Margaret Jolly (South Pentecost), Lamont Lindstrom (Tanna), Mary Patterson (North Ambrym), Margaret Rodman (Ambae), Bob Tonkinson (SE Ambrym and Mele-Maat), and Darrell Tryon (linguistics across Vanuatu). There were discussions of the weird protocols of the Condominium governments but also how approval by colonial authorities did not imply acceptance by people in local communities. Michael Allen told us stories of how the famous Church of Christ leader Abel Bani first rejected his request to study kastom in Nduindui, because he said they had left darkness behind in going long skul. Bob Tonkinson told us how Mele-Maat people were also reluctant about him, believing that his white skin may not survive the attacks of Anopheles mosquitoes but also that some suspected he might be a returning dead spirit.

Indigenous research started in the colonial period too, fostered by the development of the fieldworker system from 1980 by Kirk Huffman (a respected absent presence at the conference), together with Darrell Tryon, Advisor to the

1 This epilogue was published in the Vanuatu newspaper The Independent, on November 12, 2006, and has not been updated here for reasons of provenance. 
men fieldworkers from then until now. Some of the earliest men fieldworkers, honoured in the closing ceremony, presented papers too: Richard Leona, ${ }^{2}$ on the history of fieldworkers and their collaboration with outside researchers; Phillip Tepahae on his life's work on Aneityumese language and culture (including the Aneityum dictionary with John Lynch) and James Gwero, who worked both with his age-mate Michael Allen on Ambae in the 1960s and later with Lamont Lindstrom on the oral histories of World War Two from 1987 to 1989. Their conjoint research came out as Big Wok, an early model of collaborative research, with versions published both in Bislama and English.

We were also reminded of the long pause during the moratorium on most foreign research from 1984-1994, and how when it recommenced it did so with an exemplary set of research guidelines. These emphasise the importance of considering the aims of research in the context of the needs and priorities of communities and the importance of collaboration with ni-Vanuatu and with local fieldworkers where possible. These guidelines, introduced under the aegis of the then new Director Ralph Regenvanu, developed guiding ethical principles which have been used as a model both by UNESCO and the World Intellectual Property Organization (WIPO). Matthew Spriggs became the proud holder of VKS Research Permit Number One! We heard about how, from the late 1980s, the late Grace Mera Molisa insisted that since women were an integral and complementary part of Vanuatu's culture there should be a parallel stream of women fieldworkers. That started in 1994 and like the men's network has grown considerably with now close to 40 women fieldworkers from most parts of the archipelago.

Women fieldworkers were a notable presence as presenters and discussants at this conference. They had just finished another successful annual workshop with Jean Tarisesei, Co-ordinator and Lissant Bolton, Advisor, on the theme of kastom dress. Numalin Mahana gave a fascinating perspective from Tanna on indigenous disaster foods; Rosalyne Garae spoke with quiet eloquence about patterns of parenting and child nurture on Ambae; while Jean Tarisesei and some of the team of women fieldworkers gave interesting reflections on collaborations within Vanuatu. Margaret Rodman spoke to the collaborative project House Girls Remember, along with Numalin Mahana and Leisara Kalotiti. This research generated important insights about domestic workers from the colonial period to the present, not just about wages and eating and sleeping conditions but perceptions of their work and their relations with employers. The book from that workshop (House-Girls Remember, edited by Rodman, Kraemer, Bolton and Tarisesei, University of Hawai'i Press) was one of four launched during the conference.

2 Editors' note: regretfully not included in this volume due to a technical fault in recording conference. 
Archaeology has been another area of exemplary collaboration between overseas and ni-Vanuatu researchers and between ni-Vanuatu. About a decade ago, VKS Director Ralph Regenvanu with Matthew Spriggs and Stuart Bedford of the Australian National University (ANU) initiated a new project of research focused not just on new excavations but also on educating ni-Vanuatu about 'olfala histri wea i stap andanit long graon'. That research has proved hugely successful, generating exciting and well-publicised discoveries from the Roi Mata sites at Mangaliliu and the excavations at Teouma, and training many ni-Vanuatu men and women in the skills of archaeology while raising broader community awareness. As Stuart Bedford pointed out it was Salkon Yona, a ni-Vanuatu fieldworker from Epi who first identified the Lapita pot (dug up and kept by a bulldozer driver) which led to the extraordinary discoveries at Teouma. Because of the extensive coverage of volcanic ash, Lapita had been harder to find in Vanuatu than other Pacific sites, but since this work Vanuatu has become focal to the prehistory of Lapita. We celebrated such recent archaeological research with the launch of Stuart's book Pieces of the Vanuatu Puzzle (Pandanus, ANU, 2006). We also heard about the making of modern 'saucepans', the contemporary manufacture of pottery at Olpoi and Wusi villages from Yoko Nojima of the University of Hawai'i. The success of such public awareness and excitement about archaeology is perhaps partly behind the community support for the submission of the Roi Mata Heritage Site to UNESCO. Douglas Kalotiti (Coordinator of the Men Fieldworkers) explained the process of working through that submission (recently completed with the collaboration of Chris Ballard and Meredith Wilson of the ANU, who were unable to be present because their second baby is imminent). He explained how local custodians of the land were persuaded to move from and stop using the areas concerned because of the perceived significance of this site for future generations. Many participants joined in a visit to the Roi Mata domain in a tour after the conference.

Another area of research where we heard some stunning examples of recent collaborative research was in language, story-telling and music. Linguistic research has moved on from the days when, as instructed by Darrell Tryon, in my own recordings and learning of the Sa language of South Pentecost the main instruments were the reel-to-reel tape recorder, hours of painful transcriptions in International Phonetic Alphabet and translations with patient interlocutors. As Nick Thieberger demonstrated from his work on the language of South Efate (strangely neglected til now), new technologies include the video recording of conversations and stories, the use of new software, and the creation of multimedia dictionaries in which, for example, the detail of species of flora and fauna named in local languages can be accompanied with photographs. These new technologies evince a sense of vibrancy about language and culture and of collaborative conversation. Local interlocutors are no longer just the sources of words, stories, and voices in experiments in phonetic differentiation but 
like Phillip Tepahae, they may be co-authors of grammars and dictionaries. Together with linguists from the ANU and Sydney University, Nick has also been collaborating with the VKS in the digitisation and archiving of early audio recordings. We celebrated in launching Nick's recent book from his doctoral research, A Grammar of South Efate, which as he proclaimed to the non-linguists present, was not dry and technical but fascinating! Other interesting discussions of language and oral traditions came from Michel Wauthion and Patrick Rory on Vao language, Robert Early on the socio-linguistics of endangered languages and Janet Dixon and Takaronga Kuautonga on Futuna stories. Their book Nokonofo Kitea: We Keep On Living This Way, (Crawford/UH Press), also launched at the conference, presents Futuna stories not as frozen texts, but as living oral culture, articulating and reflecting on contemporary predicaments such as globalisation and climate change.

Another superb presentation came from Monika Stern, representing a French team from CNRS and Lacito, presently researching the music of Penama and Torba Provinces. We witnessed the differences of song poetry performed for a public dance performance, with the accompaniment of drum and resounding feet, and in the quieter context of solo and choral performance. The blue lines of computer sonic graphics graphically demonstrated the underlying structure of the music. The extraordinary beauty of the song poetry was then translated into French and the poignant melody line, translated into Western notation, was demonstrated by Monika on a violin.

It was especially gratifying to see so many younger researchers presenting at this conference, both from Vanuatu and overseas. I had a particular parochial pride in hearing papers by several younger researchers whom I have been fortunate to work with at the ANU. Stephen Zagala spoke on the relationality of sand-drawing and on how the UNESCO project which he authored declared sand-drawing a 'masterpiece of intangible heritage'. This entailed not just a collaboration between ni-Vanuatu and himself but catalysed new exchanges and collaborations between ni-Vanuatu, men and women. Jack Taylor spoke about his collaboration with Kolombas Todali, fieldworker in North Pentecost, and how he perceived that rites of accepting researchers as part of family, of advancing them in the stages of learning powerful knowledge, and celebrating with them the products of knowledge returned (theses, books, papers etc.) were all part of a process which gave rights to researchers through rites. It echoed a conversation I had had earlier in the week with Chief Telekon of Bunlap (now living in Erakor), when he affirmed that I was still family with people in Bunlap, and told me that my research and book had helped raise up kastom in South East Pentecost. I read a paper by Sabine Hess, now back in Heidelberg, whom I had supervised at the ANU, reflecting on some of the personal challenges while researching with fieldworker Eli Field on Vanua Lava. She explored the tensions 
between their relationship as father and daughter and as man fieldworker and woman anthropologist and agreed with Eli that her fieldwork had been a 'good hard time'. She reminded new researchers how important it was to respect local protocols about not breaching tabu places or tabu stories. This echoed local stories retold by Jack Taylor about Bernard Deacon's death on Malakula, not just the result of black water fever but because he visited a tabu place despite strong warnings.

As in Sabine Hess' talk, the collaborative system of research with fieldworkers was critically considered, in terms of the gendered dynamics of collaboration and in how it might re-emphasise a 'key informant' approach to anthropology rather than dynamic ethnography and participant observation. And, as Benedicta Rousseau pointed out in her paper, grounded in her work with the Young People's Project, it is important to be able to discuss kastom between islands (given patterns of exchange, mobility, urbanisation and inter-island marriage) and to discuss kastom at the shared national level and not just as the particular kastom of one place. It was heartening to see experienced researchers like Mary Patterson, renowned for her early work on kinship, place and sorcery on Ambrym working again in Vanuatu, between towns and villages, on national questions about 'managing modernity' with collaborators like Ileen Vira. Mary's past kinship connections are being remade in the present, as in her research collaboration with Koran Wilfred, grandson of her original host family.

Most younger researchers from overseas seem to have developed excellent collaborative relations either through the connections of the fieldworker system or more generally through VKS or through earlier work or volunteer experience in Vanuatu. Miranda Forsyth, who once worked as an Australian volunteer in the Public Prosecutor's Office is now completing an important study of the relation between state and customary systems of dispute resolution. Sara Lightner, who first came to Vanuatu as a Peace Corps Volunteer and is widely respected as the co-author of the wonderful Histri Blong Yumi (with Anna Naupa), is now doing pioneering research for her Masters at the University of Hawai'i on the indigenous Catholic sisters of Melsisi. Some research presented has a strong potential for a policy impact: Margaret Malloch and Morris Kaloran spoke to their conjoint work for AusAID on women and equity in Vanuatu: Catherine Sparks from Canada gave a scintillating presentation on whether ni-Vanuatu women's everyday commitment to food production and care of their children could be read as 'resistance' to the high church of neo-liberal economics; and Jacqueline Marshall spoke of her 'action research', on the possible introduction of backpacker tourism into the villages of Mele and Mele-Maat.

The centrality of the visual in recording, analysing and preserving contemporary Vanuatu culture was highlighted. Marc Tabani not only gave a passionate report on his continuing research on John Frum in Tanna, and his accumulating 
'millenium archives', but also presented an excellent film. Jacob Kapere screened this and several other films during the lunch breaks and spoke to us about the crucial importance of the Film Unit of VKS not just as a 'kastom bank' of visual records from the past but as a process of recording the living culture of Vanuatu, as in several films he has made or been associated with as advisor. As Lissant Bolton reminded us in a speech (and in an entertaining paper she gave about the dispute about the Unification Church in 2005), culture in Vanuatu is constantly being created and changing.

Several presentations stressed how crucial the VKS is as both a site and a source of research, in the resources of its museum, its library, film unit, and several associated projects and especially in the experience of its extraordinarily talented team of staff, fieldworkers and volunteers (including the dedicated Friends of the Museum). Martha Yamsiu spoke of the foundational work of the Vanuatu Cultural and Historic Sites Survey (VCHSS), and William Mohns explained how VKS was creating a digital archive of the collections. Susan Cochrane brought materials from a recent workshop involving South Sea Islanders in Brisbane and showed images of some of the kastom collection of objects associated with labourers on Queensland's sugar fields and their descendants, now held in the Queensland Museum. But, Peter Murgatroyd of the University of the South Pacific reminded us of how important it was to move knowledge beyond the walls of museums and libraries, beyond Vila to the outer islands and to the world, with the use of new digital technologies. Clearly digital libraries and websites such as he is building at USP are hopeful developments, as is increasing dissemination of research in Bislama, as well as English and French, and the use of open-access publications. But, as those with close experience of islands beyond Vila (and indeed in some villages and settlements just down the road) know accessibility is not just a matter of geography but of money and power. And so the earlier technologies of paper and videos may prove important for a while yet. In conclusion, I want to congratulate and thank the organisers, the presenters, the staff and the fieldworkers of VKS for a stunning event. It was a fitting tribute to Ralph Regenvanu who is due to retire at the end of December after having been an energetic and charismatic Director of VKS for about eleven years. The VKS has become a model institution in the Pacific region and internationally as a place dedicated to living culture and collaborative research. May it continue to thrive and let us hope this experience was not unique, in that something similar might be repeated before too long. 


\section{References}

Bedford, Stuart 2006 Pieces of the Vanuatu Puzzle: Archaeology of the North, South and Centre. Canberra: Pandanus Press, Australian National University. Terra Australis 23.

Jolly, Margaret, 2006. A Personal Perspective on After 26 Years: Collaborative Research in Vanuatu since Independence, The Independent, 12 November 2006.

Keller, Janet Dixon 2007. Nokonofo Kitea: We Keep on Living this Way: Myths and Music of Futuna Vanuatu. Honolulu: University of Hawai'i Press.

Lightner, Sara and Anna Naupa 2005. Histri Blong Yumi Long Vanuatu. 3 volumes plus teacher's guide. Port Vila: Vanuatu Cultural Centre.

Rodman, Margaret, Daniela Kraemer, Lissant Bolton and Jean Tarisesei (eds), 2007. House-Girls Remember: Domestic Workers in Vanuatu. Honolulu: University of Hawai'i Press.

Thieberger, Nicholas. 2006. A Grammar of South Efate: An Oceanic Language of Vanuatu Oceanic Linguistics Special Publication, No. 33. Honolulu: University of Hawai'i Press. 